\title{
The Effects of Federal Policies on Rangeland Ecosystem Services in the Southwestern United States
}

\author{
By Aaron M. Lien, Jenny L. Neeley, George B. Ruyle, and Laura López-Hoffman
}

\section{On the Ground}

- Rangelands provide a wide array of ecosystem services - the direct benefits people receive from nature. There is increasing interest by policymakers and conservationists in managing for these ecosystem services.

- Because of complex land tenure arrangements in the Intermountain West, it is important to understand the impacts of federal resource management laws on ecosystem services flowing from public and private lands.

- All major federal land management laws are supportive of managing for ecosystem services. We review the implications of FLPMA, NFMA, NEPA, ESA, and CWA on ecosystem services on public and private lands.

Keywords: ecosystem services, public lands, federal policy, US Forest Service, Bureau of Land Management, NEPA.

Rangelands 37(4):152-157

doi: 10.1016/j.rala.2015.05.002

(C) 2015 The Society for Range Management

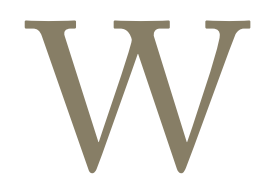

hen the rains come to the Southwest, often as downpours, healthy expanses of grassland capture and slow the flow of the storm water and, in the process, help recharge groundwater and control erosion. The range thus providesin addition to forage for livestock and habitat for wildlife - many benefits, such as flood control, water supply, and soil protection. These benefits - that people receive directly or indirectly from nature-are called ecosystem services. ${ }^{1}$ In general, Southwestern rangelands, when managed sustainably, provide four types of ecosystem services:

- Provisioning services supply sources of forage for livestock and wildlife; food for humans, such as from beef production; and renewable resources, such as timber.

- Supporting services sustain the basic functioning of rangeland ecosystems through nutrient cycling in soil, photosynthesis by plants, and other means.

- Protecting services help nature absorb, or regulate, potentially harmful disturbances, such as by buffering against flooding in heavy rains.

- Cultural services provide a basis for human enjoyment through recreation and tourism, and support spiritual, religious, or aesthetic values.

Across the Southwest and elsewhere, there is growing interest among landowners, resource managers, and researchers to better understand how ecosystems - such as rangelands, forests, and streamside areas - function and to identify the types and value of the services they provide to society. ${ }^{2}$ Relatedly, there is a need to look more closely - from the perspective of ecosystem servicesat the effects of different resource management approaches to see which options yield the most benefits, and why. ${ }^{3-5}$ Knowledge from such studies could guide policies and programs for land management, such as providing economic incentives to private landowners to help them sustain existing ecosystem services or derive new ones from their lands. ${ }^{6}$ As it stands now, there are few incentive programs, economic or otherwise, to encourage landowners to maintain or generate ecosystem services through sustainable range management.

Although the concept of ecosystem services has emerged as a tool for natural resources management, generally, its use for rangeland management is limited. Several publications - including articles in a special issue of Rangelands (October 2011) - have discussed ecosystem services provided by sustainable range management, showing a clear interest in the topic by researchers and land managers. ${ }^{7,8}$ However, there are few documented 
examples of policies or programs that explicitly consider ecosystem services as a factor in decision making. This is particularly striking for federal laws and regulations, which guide resource management for significant portions of the western United States.

\section{Federal Policies and Rangeland Ecosystem Services}

All of the major public land management laws predate the emergence of the ecosystem service framework as an approach to analyze and manage natural resources. Despite this, federal natural resources policies do influence what, how, and where ecosystem services are produced on Southwestern rangelands, especially on public lands.

Five federal laws, in particular, have a disproportionate effect on public lands used for livestock grazing: the Federal Land Policy and Management Act (FLPMA), the National Forest Management Act (NFMA), the National Environmental Policy Act (NEPA), the Endangered Species Act (ESA), and the Clean Water Act (CWA). The first two laws govern the core functions, respectively, of the Bureau of Land Management (BLM) and the U.S. Forest Service, which manage most of the public lands on which grazing takes place. The latter three laws guide key national environmental policies.

In the following sections, we describe the purpose and intent of these laws and their related policies. We review the potential effects the laws might have on the provision of ecosystem services from public rangelands. We also note when and how each law might affect ecosystem services on private land.

\section{Federal Land Policy and Management Act}

\section{Purpose}

The FLPMA authorizes the BLM to manage public lands with a stated goal of multiple use and sustained yield. The FLPMA requires comprehensive land-use planning for all BLM lands, defines the basic functions of the agency, and provides guidelines to manage grazing lands and rights of way.

\section{Effects on Public Lands}

While the term ecosystem services does not appear in the FLPMA, the law does affect the provision of ecosystem services from BLM lands simply by regulating the management of those lands. The FLPMA contains several formal declarations of policy, stating that:

the public lands [will] be managed in a manner that will protect the quality of scientific, scenic, historical, ecological, environmental, air and atmospheric, water resource, and archeological values; that, where appropriate, will preserve and protect certain public lands in their natural condition; that will provide food and habitat for fish and wildlife and domestic animals; and that will provide for outdoor recreation and buman occupancy and use. ${ }^{9}$

In essence, this policy calls for the maintenance of ecosystem services on BLM-managed lands.
Resource management plan

The FLPMA requires the BLM to develop resource management plans for the public lands it manages. A resource management plan provides general direction for how the BLM will manage lands in a given region to meet the agencies objectives for multiple use and sustained yield. Resource management plans are typically developed at the field office or unit level. For example, in Arizona, there are separate resource management plans in place for the Ironwood Forest National Monument, a monument managed by the BLM, and for the Lower Sonoran Decision Area, an area managed by the BLM's Lower Sonoran Field Office.

The FLPMA provides only general guidelines to develop resource management plans. The law contains no requirement for how frequently plans must be developed or updated. In creating plans, the BLM is required to follow the principles of multiple use and sustained yield, apply an interdisciplinary approach that considers both natural resources management and economics, prioritize protection of areas designated as having special environmental values, consider all potential uses of public lands, consider long-term and short-term benefits of planning decisions, comply with applicable pollution control laws, and coordinate with other agencies and Native American tribes.

In practice, the BLM resource management plans generally do not apply an ecosystem services framework. For example, the recently completed Lower Sonoran Resource Management Plan in Arizona makes no mention of the phrase ecosystem services. However, the BLM plans do affect the provision of ecosystem services from the lands the agency manages. The decisions made in a resource management plan-including those about grazing, recreation, and conservation planning-have a significant impact on the ability of the planning unit to continue to provide certain ecosystem services. Furthermore, the effects of BLM planning on ecosystem services are specific to each resource management plan.

\section{Public lands grazing management}

The FLPMA also contains regulations for grazing on federal lands, including rules for grazing fees, leases, and permits. The federal grazing program is a use of a provisioning ecosystem service- forage - provided by the public lands. The FLPMA acknowledges that public rangelands in the western United States were degraded at the time the Act was passed in 1976. The law seeks to improve range conditions by modifying the grazing program and authorizing funding for range improvements. In effect, these policies seek to improve the flow of ecosystem services from public rangelands.

The BLM and the U.S. Forest Service (only for forests in the 16 western states, excluding Hawaii and Alaska) have discretionary authority to develop allotment management plans for grazing. Allotment management plans specify how grazing and range management will take place on a given allotment, including the size of the herd and the seasons the allotment may be used for grazing. The conditions set out in the allotment management plan, or in the grazing permit itself, will impact the type and quantity of ecosystem services provided by public lands.

\section{Effects on Private Lands}

The FLPMA applies only to federal lands managed by the BLM (and the U.S. Forest Service as it relates to grazing 
management) and does not have a direct impact on private lands. However, planning and management decisions that affect ecosystem service provision from public lands may also impact the users of those services on private lands. For example, implementation of a management plan calling for forest thinning may impact water-related ecosystem services. Forest thinning can reduce fire risk and increase the ability of the forest to provide clean water to downstream users. Management plans also designate uses for different parts of the landscape, impacting cultural services, such as recreation and aesthetic value. The public may engage in the BLM planning process through public meetings, public comment periods, and the NEPA process (see below).

\section{National Forest Management Act}

\section{Purpose}

The NFMA is the primary legal directive for the management of national forest lands by the U.S. Forest Service. The NFMA requires resource management planning for every national forest every 15 years and provides the legal framework for the U.S. Forest Service's timber sale program.

\section{Effects on Public Lands}

Without mentioning ecosystem services specifically, NFMA has a significant impact on the flow of ecosystem services from national forests. The explicit resource management mandate of NFMA is:

to serve the national interest, the renewable resource program must be based on a comprehensive assessment of present and anticipated uses, demand for, and supply of renewable resources from the Nation's public and private forests and rangelands, through analysis of environmental and economic impacts, coordination of multiple use and sustained yield opportunities as provided in the Multiple-Use, Sustained-Yield Act of 1960, and public participation in the development of the program. ${ }^{10}$

The mandate of the U.S. Forest Service, similar to that of the BLM, is multiple use and sustained yield of natural resources from the national forests. This policy affects provisioning ecosystem services, such as timber, and other ecosystem services, such as clean water and recreation.

\section{National forest planning}

The NFMA provides general guidelines for land use and resource management planning for the national forests. These guidelines are interpreted and enacted by the U.S. Forest Service through the Planning Rule, which was last updated in 2012. The NFMA requires forest plans explicitly provide "for multiple use and sustained yield of the products and services obtained therefrom." 10 The "products and services" include "outdoor recreation, range, timber, watershed, wildlife and fish, and wilderness." 10 This scope covers a wide range of ecosystem services, including provisioning services, such as timber production; regulating services, such as clean water and flood control provided by watersheds; cultural services, including recreation; and supporting services, such as biodiversity.
The 2012 Planning Rule provides specific guidance to implement the planning mandates of the NFMA. The Planning Rule requires detailed resource assessments for each national forest. The rule's intent is to provide collaborative, science-based management of the national forests. Forest plans must take into account social, economic, and ecologic resources. In addition, the Planning Rule requires a landscape-scale approach to planning. This means that forest plans must consider resources inside national forests and resources on private lands adjacent and near national forests. The goal of the landscape-scale approach is to understand the impacts of management on national forests on neighboring resources.

The 2012 Planning Rule is also one of the few federal policies to explicitly incorporate the concept of ecosystem services and to require consideration of the impacts of U.S. Forest Service management on the ecosystem services provided by national forests. ${ }^{11}$ The specific impacts on particular ecosystem services and the priorities of a given national forest are dependent on the specifics of the forest plan for each national forest.

\section{Timber sale program}

The NFMA also provides guidelines for how the U.S. Forest Service must carry out its timber sale program. The timber sale program is the primary instrument of extraction of provisioning ecosystem services from the national forests. The specific manner in which the timber sale program is executed in a given national forest will have a significant impact on ecosystem services. Timber sales also affect the ability of forests to provide other ecosystem services, such as flood control, water filtration, erosion control and sediment control, and biodiversity. Timber sale planning is a component of the forest planning process. During the planning process the overall direction of the timber sale for each national forest is set, including analysis of the impacts of timber sales on natural resources.

\section{Effects on Private Lands}

The NFMA applies only to federal lands managed by the U.S. Forest Service and does not have a direct impact on private lands. However, decisions made through the planning process that impact ecosystem services on public lands may impact users of those services on private lands. For example, timber management has impacts on water quality in streams, which may affect downstream water users. These impacts may be positive or negative, depending on the management practices used in the course logging operations. Beginning with the 2012 Planning Rule, national forests are required to take an "all lands" approach when developing forest management plans. ${ }^{11}$ The all lands approach requires the U.S. Forest Service to explicitly consider the ecologic impacts of national forest management beyond the boundaries of the federally owned forest. This is a significant change. In the past, national forest managers were not required to consider the implications of public lands management on adjacent private landowners. This mandate does not, however, give the 
U.S. Forest Service any regulatory control over neighboring private lands. The public may also participate in the U.S. Forest Service planning process through public meetings, public comment periods, and the NEPA process.

\section{National Environmental Policy Act}

\section{Purpose}

The NEPA affects all aspects of federal environmental and natural resources policy, including the management of Southwestern rangelands. The NEPA requires analysis of the environmental impacts of any major federal action. These analyses must consider alternatives to the proposed federal action and provide an environmental analysis of alternatives, including the federal agency's preferred alternative. The NEPA's requirements apply even if the federal government is only providing funding for a project, through what is called a federal nexus. A federal nexus exists when a project is supported by federal funding or otherwise requires a federal action, such as a permit, even for actions on private land. ${ }^{12}$ The purpose of the NEPA is not to regulate federal actions; instead, the law requires disclosure of the potential environmental impacts of federal actions. Because of the NEPA's requirement to consider alternatives to the proposed action and to review the environmental consequences of each option, the NEPA can act as a planning tool for both public and private land managers.

\section{Effects on Public Lands}

Although the NEPA itself does not directly regulate natural resources or land management, it does have an influence on actions taken by the federal government. All federal actions, including issuance of permits on grazing allotments and development of forest management plans, are subject to the NEPA. When issuing a grazing permit, the relevant agency (U.S. Forest Service or the BLM) must conduct an NEPA assessment, which considers the environmental impacts of grazing on public lands. This typically will include a review of alternatives based on existing management practices, on no grazing, and on a modified management regime.

The NEPA does not explicitly require the consideration of ecosystem services in environmental assessments. However, in 1999, the U.S. Environmental Protection Agency (EPA) issued guidance for how agencies should consider ecologic processes in the development of NEPA analyses. This guidance specifically calls for the evaluation of ecosystem services in the course of completing an environmental impact statement. ${ }^{13}$ For example, analysis of the impacts of grazing on public lands will necessarily include information on forage usage, soil erosion, and recreation.

\section{Effects on Private Lands}

The NEPA has limited direct impact on private lands. As mentioned above, however, in cases where private landowners are implementing management actions or other activities with federal funding, the NEPA may apply because of a federal nexus. When an NEPA evaluation is required, it helps landowners understand the potential impacts of the project on the ecosystem services provided by their property.

\section{Endangered Species Act}

\section{Purpose}

The purpose of the ESA is to "provide a means whereby the ecosystems upon which endangered species and threatened species depend may be conserved, [and] to provide a program for the conservation of such endangered species and threatened species." 14 The ESA provides a process by which the U.S. Fish and Wildlife Service may determine and legally designate a species as threatened or endangered. When a species is legally designated as threatened or endangered, it becomes illegal to harm the species in any way. The U.S. Fish and Wildlife Service may also designate "critical habitat" for threatened or endangered species. Critical habitat is an area, such as an old growth forest, considered essential to the survival and recovery of an endangered species. The purpose of critical habitat is to help promote the recovery of threatened and endangered species by identifying the most important habitat for that species. Critical habitat designations do not affect private lands, except in cases where there is a federal nexus.

\section{Effects on Public Lands}

The ESA has the potential to significantly influence the flow of ecosystem services because of the law's provisions to protect both species and species' habitats. The ESA's explicit goal of preventing extinction of plant and animal species means that the law is directly supporting biodiversity, which is a supporting ecosystem service. Similarly, by providing the authority to protect the habitat essential to preventing extinction of an endangered species, the ESA provides a means of protecting the habitat characteristics that an endangered species depends upon. These habitat characteristics may generate ecosystem services that are also beneficial to humans.

The ESA does have significant limitations in the context of protecting ecosystem services. It does not provide the authority to directly protect, manage, or restore ecosystem services. Rather, it only provides the authority to take actions to protect species from harm and to protect the habitat that is essential to the species' survival. In protecting the habitat, the emphasis is on conserving the habitat conditions that are important to the endangered species rather than for any larger habitat or ecosystem service management goal. Management actions taken to protect an endangered species' habitat may have positive or negative effects on the provision of other ecosystem services.

\section{Effects on Private Lands}

The ESA does affect private lands. When a species is listed as threatened or endangered under the provisions of the Act, it is always illegal to knowingly harm that species. Landowners 
may need to alter management practices to avoid harming endangered species. These changes may also alter the flows of ecosystem services from the landowners' property. When the U.S. Fish and Wildlife Service has designated a critical habitat for a species, activities on private lands may be subject to review by the U.S. Fish and Wildlife Service in cases where a federal nexus exists. For example, through the Farm Bill, farmers and ranchers can receive funding to implement management practices on their private lands. Because these projects are federally funded, participating farmers and ranchers must follow federal laws, including the NEPA and the ESA. When a project has the potential to impact an endangered species, the landowner or the agency funding the project must conduct a "consultation" with the U.S. Fish and Wildlife Service. A consultation is a formal review by the U.S. Fish and Wildlife Service to determine the impacts of the project on the endangered species. A consultation may result in a finding that there is no impact, a positive impact, or a negative impact on the species. When there is a negative impact, the agency may require changes to the project, prevent the project for taking place, or require that the impacts of the project be offset through protection of habitat for the impacted species at a different site.

\section{Clean Water Act}

\section{Purpose}

The CWA regulates pollution of surface waters of the United States. A surface water of the United States is any "navigable" stream or lake and includes wetlands in some cases. Any discharge of pollutants or the modification or destruction of waters of the United States is regulated by the CWA through the National Pollutant Discharge Elimination System (NPDES) permit program. The goal of the NPDES is to reduce or eliminate the release of pollutants into streams or wetlands from point sources. Point sources are direct, measurable sources of pollution, such as from a wastewater treatment plant or an industrial facility. Nonpoint sources, such as agricultural and urban runoff, are not regulated through the NPDES system. The CWA also includes provisions to prevent the destruction of wetlands. ${ }^{15}$

\section{Effects on Public Lands}

The CWA, with its focus on limiting water pollution elimination and preventing the destruction of streams and wetlands, plays a significant role in the maintenance and restoration of ecosystem services. These ecosystem services include clean water, water filtration, flood control, and erosion control. The CWA may affect rangelands by regulating impacts on streams and wetlands in areas used for grazing. For example, a rancher may need to obtain permits to modify a stream channel, even if the intent is to prevent erosion.

The CWA is the impetus for several payments for ecosystem services programs. Payments for ecosystem services are an approach to conserving and restoring ecosystem services by using incentives or markets. There are two approaches to payments for ecosystem services resulting from CWA regulations. The first is programs to reduce water pollution. These programs typically function similar to a cap-and-trade system: farmers implement practices to capture nitrogen and phosphorus that might otherwise run off of their fields and in return are able to sell discharge offsets to wastewater treatment plants. The second payment for ecosystem services program is wetland mitigation banking. When wetlands are destroyed in the course of development, the loss of wetlands may be offset through creation or restoration of wetlands elsewhere. Private landowners create and restore wetlands and sell offsets to private developers who have destroyed wetlands. The common thread between these payments for ecosystem services programs is the reduction and elimination of pollution and destruction of wetlands and streams. The CWA is a key law for the preservation of water related ecosystem service flows.

\section{Effects on Private Lands}

The CWA applies to all waters of the United States, regardless of whether they pass through public or private lands. Therefore, the CWA's regulations are applicable regardless of the type of land ownership. Specific regulations stemming from the CWA can vary from one place to another, depending on the degree of pollution in a given stream. For streams with ongoing, unaddressed pollution issues, the EPA may develop a total maximum daily load (TMDL) regulation. In the absence of a TMDL, the CWA regulates modification and destruction of streams and wetlands but does not regulate non-point source pollution. Nonpoint source pollution from animal waste is the most common type of pollution generated by agricultural production activities, including some grazing. When a TMDL is present on a stream, additional regulations may apply, including regulations that impact private landowners. These regulations, and the impact they have on ecosystem services, are specific to the circumstances of each TMDL.

\section{Conclusions}

From even a brief review of the key federal laws governing the management of western public lands, it is clear that existing policies support the provision of ecosystem services. No additional legislation is needed to enable the BLM or the U.S. Forest Service to begin to consider ecosystem services in their decision making. While the term "ecosystem services" had not been coined until after all of the significant land management laws were enacted, it is clear from the language of the laws that the drafters had what we now call ecosystem services in mind. The FLPMA, the NFMA, and the NEPA are, at their core, people-focused laws. When the NFMA speaks of ensuring clean water and when the FLPMA mandates multiple-use, sustained-yield management, the laws are directing managers to maintain ecosystem services.

Although the language of the laws provides the framework to support management for ecosystem services on public lands, 
rule making can make this goal explicit. Nowhere is this clearer than in the U.S. Forest Service's National Forest Planning Rule, which, after its 2012 update, requires consideration of management impacts on ecosystem services. Although the U.S. Forest Service was already permitted by the NFMA to manage the ecosystem services, the 2012 Planning Rule is the first explicit statement of national policy by the U.S. Forest Service's leadership that it will do so. In this respect, the 2012 Planning Rule is a model for how other land management agencies can incorporate management for ecosystem services into their planning and management processes.

\section{References}

1. Millennium Ecosystem Assessment, 2005. Ecosystems and human well-being: synthesis. Washington, DC: Island Press [Available at: http://www.who.int/entity/globalchange/ ecosystems/ecosys.pdf. Accessed 20 October 2014].

2. Nabhan, G.P., L. López-Hoffman, H. Gosnell, J. Goldstein, R. Knight, C. Presnall, L. Gwin, D. Thilmany, and S. Charnley. 2014. Payments for Ecosystem Services: Keeping Working Landscapes Productive and Functioning. In: Charnley S, Sheridan TE, \& Nabhan GP, editors. Stitching the west back together. Chicago, IL: University of Chicago Press. p. 275-294.

3. [NESP] National Ecosystem Services PartnershiP, 2015. Federal resource management and ecosystem services guidebook. Available at: https://nespguidebook.com/2015 [Accessed 12 February 2015].

4. Presnall, C., L. López-Hoffman, and M.L. Miller. 2014. Adding ecosystem services to environmental impact analyses: more sequins on a "bloated Elvis" or rockin' idea? Ecological Economics 115:29-38.

5. [USFS] U.S. Forest SERVICE, 2014. Marsh draft environmental assessment. Crescent, OR: U.S. Forest Service Crescent Ranger District [Available at: http://data.ecosystem-management.org/ nepaweb/nepa_project_exp.php?project=40231. Accessed 20 October 2014].

6. Ferraro, P.J., And A. Kiss. 2002. Direct payments to conserve biodiversity. Science 298:1718-1719.

7. MacLeod, N.D., AND J.R. BROWN. 2014. Valuing and rewarding ecosystem services from rangelands. Rangelands 36:12-19.

8. BuDD, B. 2002. Blue birds and black cows. In: Knight RL, Gilgert WC, \& Marston E, editors. Ranching west of the 100th meridian. Washington, DC: Island Press. p. 175-182.
9. [FLPMA] Federal Land Policy and Management Act, 2001. The Federal Land Policy and Managemen Act of 1976, as amended. Washington, DC: U.S. Bureau of Land Management. Available at: http://www.blm.gov/flpma/FLPMA.pdf. Accessed 20 October 2014.

10. [NFMA] National Forest Management Act, 1976. The National Forest Management Act of 1976. Washington, DC: U.S. Forest Service [Available at: http://www.fs.fed.us/emc/ nfma/includes/NFMA1976.pdf. Accessed 20 October 2014].

11. [USFS] U.S. Forest Service, 2012. 2012 Planning Rule. Washington, DC: U.S. Forest Service [Available at: http://www. fs.usda.gov/planningrule. Accessed 20 October 2014].

12. Council For Environmental Quality, 2015. CEQRegulations for Implementing NEPA. https://ceq.doe.gov/ceq_regulations/ regulations.html2015 [Accessed 12 February, 2015].

13. Environmental Protection Agency (EPA), 1999. Considering ecological processes in environmental impact assessments. Washington, DC: U.S. Environmental Protection Agency, Office of Federal Activities [Available at: http://www.epa.gov/ compliance/resources/policies/nepa/ecological-processes-eia-pg. pdf. Accessed 20 October 2014].

14. [ESA] Endangered Species Act, 1973. Endangered Species Act. Washington, DC: U.S. Fish and Wildlife Service [Available at: http://www.fws.gov/endangered/laws-policies/. Accessed 20 October 2014].

15. [CWA] Clean Water Act, 2002. Clean Water Act. Washington, DC: U.S. Senate Environment and Public Works Committee [Available at: http://www.epw.senate.gov/ water.pdf. Accessed 20 October 2014].

Authors are: Senior Researcher, Udall Center for Studies in Public Policy, The University of Arizona, Tucson, AZ, 85721 (Lien, amlien@cals.arizona.edu); Program Coordinator, Udall Center for Studies in Public Policy, The University of Arizona, Tucson, AZ 85721 (Neeley); Professor and Extension Specialist, School of Natural Resources and the Environment, The University of Arizona, Tucson, AZ, 85721 (Ruyle); and Assistant Professor, School of Natural Resources and the Environment and Udall Center for Studies in Public Policy, The University of Arizona, Tucson, AZ, 85721 (López-Hoffman). Funding for this work is provided by the US Fish and Wildlife Service. 